\title{
Antibodies to nodal/paranodal proteins in paediatric immune-mediated neuropathy
}

Desiree De Simoni, MD, Gerda Ricken, MSc, Michael Winklehner, MD, Inga Koneczny, PhD, Michael Karenfort, MD, Ulf Hustedt, MD, Ulrich Seidel, MD, Omar Abdel-Mannan, MD, Pinki Munot, MD, Simon Rinaldi, MD, Claudia Steen, MD, Michael Freilinger, MD, Markus Breu, MD, Rainer Seidl, MD, Markus Reindl, PhD, Julia Wanschitz, MD, Cinta Lleixà, PhD, Günther Bernert, MD, Klaus-Peter Wandinger, MD, PhD, Ralf Junker, MD, Luis Querol, MD, PhD, Frank Leypoldt, MD, PhD, Kevin Rostásy, MD,* and Romana Höftberger, MD*

Neurol Neuroimmunol Neuroinflamm 2020;7:e763. doi:10.1212/NXI.0000000000000763

Patients with nodal/paranodal antibodies represent a specific subgroup of inflammatory peripheral neuropathies, whose clinical presentation with a prolonged subacute phase, additional symptoms such as ataxia and tremor, and poor treatment response to IV immunoglobulin (IVIG) often differs from classic Guillain-Barré syndrome (GBS) or chronic inflammatory demyelinating polyneuropathy (CIDP). ${ }^{1}$

Previous studies on nodo/paranodopathies mainly focused on adult patients, whereas the clinical spectrum of pediatric patients is less well established. We reviewed the clinical presentation of 54 children with GBS $(n=42)$ and CIDP $(n=12)$ and retrospectively screened for antibodies against neurofascin155 (NF155), NF186, NF140, contactin-1 (CNTN1), contactinassociated protein 1 (CASPR1), and glycine-receptor (GlyR) using cell-based assays ${ }^{2,3}$; 1 patient was additionally tested with CNTN1-ELISA. ${ }^{4}$ All cases with sufficient serum were tested for ganglioside-IgG-, IgA-, and IgM-antibodies against GM1 ( $=42)$, GD1a $(\mathrm{n}=18)$, GD1b ( $=23)$, and GQ1b $(\mathrm{n}=21){ }^{5}$ Clinical and paraclinical information of all patients is summarized in the table. The study was approved by the ethics committee (EK1773/2016).

\section{Children with classic GBS}

Of 42 children with GBS, 26 were classified as acute inflammatory demyelinating polyneuropathy (AIDP), 7 as acute motor/motor-sensory axonal neuropathy (AMAN/AMSAN) by nerve conduction velocity according to Hadden criteria, ${ }^{6} 4$ as Miller-Fisher syndrome (MFS), and 2 as MFS/GBS overlap. Three patients with GBS could not be classified because of lack of nerve-conduction studies. In 25 of 35 patients (71.4\%), an infection was reported within 4 weeks before symptom onset ( 13 gastrointestinal, 4 respiratory, and 8 unspecified). Eight patients had IgG-ganglioside antibodies (19.0\%), 6 IgM (14.2\%), and 1 IgA (2.4\%). Nodal/ paranodal antibodies were not detected. Patients with AMAN/AMSAN (5/7 with reported infection: 1 campylobacter jejuni, 1 varicella-zoster virus, and 3 unspecified) were more often ganglioside antibody positive (6/7) than patients with AIDP (4/26; likelihood ratio 12.419$)$ or MFS (2/4).

\author{
Correspondence \\ Dr. Rostásy \\ k.rostasy@kinderklinik-datteln.de \\ or Dr. Höftberger \\ romana.hoeftberger@ \\ meduniwien.ac.at
}

\begin{abstract}
*These authors contributed equally to this work.
From the Division of Neuropathology and Neurochemistry (D.D.S., G.R., M.W., I.K., R.H.), Department of Neurology, Medical University of Vienna, Austria; Department of Neurology (D.D.S.), University Hospital St. Poelten, Austria; Department of General Pediatrics, Neonatology and Pediatric Cardiology (M.K.), University Children's Hospital, Heinrich Heine University Duesseldorf, Germany; Department of Neuropediatric Rehabilitation (U.H.), Vamed Clinic Hattingen, Germany; Department of Neuropediatrics (U.S.), Charité University, Berlin, Germany; Paediatric Neurology (O.A.-M.), Great Ormond Street Hospital for Children, London, United Kingdom; Dubowitz Neuromuscular Centre (P.M.), Great Ormond Street Hospital for Children, London, United Kingdom; Nuffield Department of Clinical Neurosciences (S.R.), University of Oxford and Oxford University Hospitals NHS Foundation Trust; Department of Paediatric and Adolescent Medicine (C.S.), St Joseph Hospital, Berlin, Germany; Department of Pediatrics and Adolescent Medicine (M.F., M.B., R.S.), Medical University of Vienna, Austria; Department of Neurology (M.R., J.W.), Medical University of Innsbruck, Austria; Neuromuscular Diseases Unit (C.L., L.Q.), Hospital de la Santa Creu i Sant Pau, Universitat Autónoma de Barcelona, Spain; SMZ Süd (G.B.), Kaiser-Franz Josef Hospital with Gottfried von Preyer Children Hospital, Vienna, Austria; Institute of Clinical Chemistry (K.P.W., R.J., F.L.), University Hospital Schleswig-Holstein, Kiel/Lübeck, Germany; Department of Neurology (F.L.), University Hospital Schleswig-Holstein, Kiel, Germany; and Department of Pediatric Neurology (K.R.), Witten/Herdecke University, Children's Hospital Datteln, Germany.
\end{abstract}

Go to Neurology.org/NN for full disclosures. Funding information is provided at the end of the article.

The Article Processing Charge was funded by Austrian Science Fund.

This is an open access article distributed under the terms of the Creative Commons Attribution License 4.0 (CC BY), which permits unrestricted use, distribution, and reproduction in any medium, provided the original work is properly cited. 
Table Clinical and paraclinical data of patients with GBS and CIDP

\begin{tabular}{|c|c|c|c|c|}
\hline & \multicolumn{2}{|l|}{ GBS (42) } & \multicolumn{2}{|l|}{ CIDP (12) } \\
\hline & $\begin{array}{l}\text { Ganglioside abs pos. } \\
\text { (IgG//gM/IgA) }\end{array}$ & Seronegative & $\begin{array}{l}\text { Nodal/paranodal } \\
\text { antibodies pos. }\end{array}$ & Seronegative \\
\hline No. of patients & 15 & 27 & 5 & 7 \\
\hline Age mean (range) & $11.6(4-17)$ & $10.22(1-18)$ & $7.9(3-11)$ & $10.4(4-18)$ \\
\hline Gender m:f & $9: 6$ & $15: 12$ & $3: 2$ & $4: 3$ \\
\hline AIDP & 4 & 22 & & \\
\hline AMAN/AMSAN & 6 & 1 & & \\
\hline MFS/MFS overlap & $3 / 1$ & $1 / 1$ & & \\
\hline GBS no NCS & 1 & 2 & & \\
\hline GM1+ & 6 & - & 0 & 0 \\
\hline GD1a+ & 1 & & 0 & 0 \\
\hline GD1b+ & 1 & & 0 & 0 \\
\hline GM1+GD1b+ & 4 & & 0 & 0 \\
\hline GQ1b+ & 1 & & 0 & 0 \\
\hline GM1+GD1a+GQ1b+ & 1 & & & \\
\hline GD1a+GQ1b+ & 1 & & & \\
\hline Pan-neurofascin+ & - & - & 2 & 0 \\
\hline NF155+ & & & 1 & 0 \\
\hline CNTN1+ & & & 2 & 0 \\
\hline CSF mean cell count/ $\mu \mathrm{L}$ (range) & $3.15(0-11)$ & $2.92(0-11)$ & $4.6(0-21)$ & $3.8(1-9)$ \\
\hline CSF mean total protein $\mathrm{mg} / \mathrm{dL}$ (range) & $98.08(10-250)$ & $118.59(19-401)$ & $292.4(75-619)$ & $107.7(24-288)$ \\
\hline Infection (data available from 45/54) & $\begin{array}{l}11 \text { (2 C. jejuni; } 1 \text { VZV; } 8 \\
\text { unspecified) }\end{array}$ & $\begin{array}{l}14 \text { (2 C. jejuni; } 3 \text { VZV; } 1 \text { EBV; } 8 \\
\text { unspecified) }\end{array}$ & 1 & 2 \\
\hline GI & 6 & 7 & 1 & 0 \\
\hline Respiratory & 2 & 2 & 0 & 2 \\
\hline Other & 3 & 5 & 0 & 0 \\
\hline Infection d prior mean (range) & $9(1-14)$ & $11.6(3-28)$ & 0 & $4.8(1-10)$ \\
\hline Days hospitalization mean (range) & $13.43(3-30)$ & $20.73(0-135)$ & $13(2-28)$ & $10.4(2-16)$ \\
\hline Cranial nerve involvement & 3 & 7 & 1 & 2 \\
\hline Autonomic dysfunction & 1 & 2 & 0 & 0 \\
\hline Tremor/ataxia & 3 & 3 & 5 & 1 \\
\hline $\begin{array}{l}\text { Outcome mRS (available from } 32 / 42 \text { GBS } \\
\text { and } 11 / 12 \text { CIDP) }\end{array}$ & $\begin{array}{l}11 \text { mRS 0-1; } 1 \text { mRS 2-4; } \\
1 \text { mRS >1; }\end{array}$ & $\begin{array}{l}15 \mathrm{mRS} 0-1 ; 4 \mathrm{mRS} 2-4 ; 1 \mathrm{mRS} \\
5-6 ; 5 \mathrm{mRS}>1\end{array}$ & $\begin{array}{l}2 \mathrm{mRS} 0-1 ; 3 \mathrm{mRS} 2-4 ; \\
3 \mathrm{mRS}>1 ;\end{array}$ & $\begin{array}{l}2 \mathrm{mRS} 0-1 ; 4 \mathrm{mRS} \\
2-4 ; 4 \mathrm{mRS}>1\end{array}$ \\
\hline $\begin{array}{l}\text { Severity at nadir HS (available from } 41 / \\
42 \text { GBS and } 12 / 12 \text { CIDP) }\end{array}$ & $\begin{array}{l}2 \mathrm{HS} 1 ; 8 \mathrm{HS} 2 ; 1 \mathrm{HS} 3 ; 2 \\
\text { HS4; } 1 \text { HS5 }\end{array}$ & $\begin{array}{l}2 \text { HS1; } 5 \text { HS2; } 7 \text { HS3; } 6 \text { HS4; } 6 \\
\text { HS5; } 1 \text { HS6 }\end{array}$ & 3 HS3; 2 HS4 & $2 \mathrm{HS} 1 ; 1 \mathrm{HS} 2 ; 4 \mathrm{HS} 4$ \\
\hline
\end{tabular}

Abbreviations: AIDP = acute inflammatory demyelinating polyneuropathy; AMAN = acute motor axonal neuropathy; AMSAN = acute motor and sensory axonal neuropathy; $C$. jejuni = campylobacter jejuni; CIDP = chronic inflammatory demyelinating polyneuropathy; EBV = Epstein-Barr virus; GBS = GuillainBarré syndrome; GI = gastrointestinal; HS = Hughes score; MFS = Miller-Fisher syndrome; mRS = modified Rankin Scale; NCS = nerve-conduction study; VZV = varicella-zoster-virus. 


\section{Children with nodal/ paranodal antibodies}

Five of 12 children, who met the EFNS/PNS criteria for CIDP, had nodal/paranodal antibodies: 2 pan-neurofascin (NF155/ NF186/140 triple positive), 1 NF155, and 2 CNTN1antibodies. The IgG-subclass distribution was determined by flow cytometry analysis. ${ }^{7}$ IgG4 was the predominant subclass in all patients and ranged from $75 \%$ to $100 \%$. In addition, 1 patient with pan-neurofascin-antibodies tested positive for GlyRantibodies but did not develop stiff-person syndrome or progressive encephalomyelitis with rigidity, and the significance of this finding needs further investigation. The mean age was 7.9 years (range 3-11), and the male:female ratio was 3:2. The median duration of hospitalization was 13 days (range 2-28). One pan-neurofascin-patient was initially diagnosed as GBS and reclassified as CIDP during disease course, the other patients had a chronic onset with slow progression over months or years. One child had a gastrointestinal infection before symptom onset. One CNTN1-patient showed cranial nerve involvement and optic neuritis during disease course. All children had ataxia, 4 neuropathic pain (all except 1 pan-neurofascin), and 3 (2 CNTN1, and 1 pan-neurofascin) tremor. At the peak of disease, 3 children needed a walking aid (Hughes 3 ) and 2 were bedridden (Hughes 4). None of the children had renal dysfunction. The mean CSF white cell count was $4.6 \mu \mathrm{L}$ (range 0-21), and the mean CSF protein was $292.4 \mathrm{mg} / \mathrm{dL}$ (range 75-619).

The mean time of follow-up was 32 months (range 17-57). The 2 CIDP patients with pan-neurofascin-antibodies initially showed no or only partial response to IVIG and therefore received corticosteroids, 1 along with plasma exchange and the other with mycophenolate. Both recovered only very slowly over up to 4 years with a modified Rankin Scale (mRS) score of 1 at the last follow-up. The NF155-patient did not respond to IVIG and corticosteroids and subsequently received immunoadsorption and rituximab, leading to significant clinical improvement. After 8 months, he relapsed in association with normalization of the CD19/20 ratio and again rapidly improved after another dose of rituximab, with a mRS score of 2 at the last follow-up. One patient with CNTN1-antibodies worsened despite monthly IVIG and corticosteroids given over 4 months. After treatment was switched to rituximab, he improved rapidly in the following weeks and remained stable since then. The second child with CNTN1-antibodies showed only partial response to IVIG with relapses in conjunction with infections. This child improved significantly after rituximab application with a mRS score of 2 at the last follow-up.

In summary, our study demonstrates that nodal/paranodal antibodies occur in a subgroup of paediatric patients with CIDP, but not GBS. Children with AMAN/AMSAN frequently have ganglioside antibodies. Children with CIDP and atypical/prolonged disease course with high Hughes score $(>2)$, sensory ataxia, prominent neuropathic pain, and tremor may have nodal/paranodal antibodies. These patients often do not sufficiently respond to IVIG, whereas in our case series, rituximab led to prompt improvement in 3 children. Optimal treatment strategies for children with nodal/paranodal antibodies have to be further determined in larger studies.

\section{Acknowledgment}

The authors thank Valerie Pichler and Sopie Dürauer for technical assistance and Andreas Spittler from the Flow Cytometry Core facility of the MUV for technical support.

\section{Study funding}

This work was partly supported by grants from the "Jubiläumsfonds der Österreichischen Nationalbank," project 16919 (R. Höftberger), the GBS/CIDP Foundation International (J. Wanschitz), Austrian Science Fund FWF, DOC 33-B27 (R. Höftberger, M. Winklehner) and I3334-B27 (R. Höftberger), Hertha Firnberg project number T996-B30 (I. Koneczny), the PI16/000627 grant of the Fondo de Investigaciones Sanitarias-Instituto de Salud Carlos III (fondos FEDER) (L. Querol), personal grant SLT006/17/00131 of the Pla estratègic de Recerca i Innovació en Salut (PERIS), Departament de Salut, Generalitat de Catalunya (L. Querol), and the German Ministry of Education and Research (BMBF, 01 GM1908A).

\section{Disclosure}

D. De Simoni, G. Ricken, M. Winklehner, I. Koneczny, M. Karenfort, U. Hustedt, U. Seidel, O. Abdel-Mannan, P. Munot, S. Rinaldi, C. Steen, M. Freilinger, M. Breu, R. Seidl, M. Reindl, J. Wanschitz, C. Lleixá, G. Bernert, K.P. Wandinger, R. Junker, L. Querol, F. Leypoldt, K. Rostásy, and R. Höftberger report no disclosures relevant to the manuscript. Go to Neurology.org/NN for full disclosures.

\section{Publication history}

Received by Neurology: Neuroimmunology \& Neuroinflammation March 8, 2020. Accepted in final form April 29, 2020.

Appendix Authors

\begin{tabular}{lll}
\hline Name & Location & Contribution \\
\hline $\begin{array}{l}\text { Desiree De } \\
\text { Simoni, MD }\end{array}$ & $\begin{array}{l}\text { Medical University of } \\
\text { Vienna, Austria; University } \\
\text { Hospital St. Poelten, } \\
\text { Austria }\end{array}$ & $\begin{array}{l}\text { Acquisition of data, } \\
\text { statistical analysis, } \\
\text { execution, and } \\
\text { interpretation of data }\end{array}$ \\
\hline $\begin{array}{l}\text { Gerda } \\
\text { Ricken, MSc }\end{array}$ & $\begin{array}{l}\text { Medical University of } \\
\text { Vienna, Austria }\end{array}$ & $\begin{array}{l}\text { Acquisition of data, } \\
\text { execution, interpretation } \\
\text { of data, and critical review } \\
\text { for important intellectual } \\
\text { content }\end{array}$ \\
\hline $\begin{array}{l}\text { Michael } \\
\text { Winklehner, } \\
\text { MD }\end{array}$ & $\begin{array}{l}\text { Medical University of } \\
\text { Vienna, Austria }\end{array}$ & $\begin{array}{l}\text { Statistical analysis and } \\
\text { critical review for } \\
\text { important intellectual } \\
\text { content }\end{array}$ \\
\hline $\begin{array}{l}\text { Inga } \\
\text { Koneczny, } \\
\text { PhD }\end{array}$ & Medical University of & $\begin{array}{l}\text { Acquisition of data, } \\
\text { execution, interpretation } \\
\text { of data, and critical review } \\
\text { for important intellectual } \\
\text { content }\end{array}$ \\
& &
\end{tabular}


Appendix (continued)

\begin{tabular}{|c|c|c|}
\hline Name & Location & Contribution \\
\hline $\begin{array}{l}\text { Michael } \\
\text { Karenfort, } \\
\text { MD }\end{array}$ & $\begin{array}{l}\text { University Children's } \\
\text { Hospital, Heinrich Heine } \\
\text { University Duesseldorf, } \\
\text { Germany }\end{array}$ & $\begin{array}{l}\text { Acquisition of data and } \\
\text { critical review for } \\
\text { important intellectual } \\
\text { content }\end{array}$ \\
\hline $\begin{array}{l}\text { Ulf Hustedt, } \\
\text { MD }\end{array}$ & $\begin{array}{l}\text { Vamed Clinic Hattingen, } \\
\text { Germany }\end{array}$ & $\begin{array}{l}\text { Acquisition of data and } \\
\text { critical review for } \\
\text { important intellectual } \\
\text { content }\end{array}$ \\
\hline $\begin{array}{l}\text { Ulrich } \\
\text { Seidel, MD }\end{array}$ & $\begin{array}{l}\text { Charité University, Berlin, } \\
\text { Germany }\end{array}$ & $\begin{array}{l}\text { Acquisition of data and } \\
\text { critical review for } \\
\text { important intellectual } \\
\text { content }\end{array}$ \\
\hline $\begin{array}{l}\text { Omar Abdel- } \\
\text { Mannan, MD }\end{array}$ & $\begin{array}{l}\text { Great Ormond Street } \\
\text { Hospital for Children, } \\
\text { London, United Kingdom }\end{array}$ & $\begin{array}{l}\text { Acquisition of data and } \\
\text { critical review for } \\
\text { important intellectual } \\
\text { content }\end{array}$ \\
\hline $\begin{array}{l}\text { Pinki Munot, } \\
\text { MD }\end{array}$ & $\begin{array}{l}\text { Great Ormond Street } \\
\text { Hospital for Children, } \\
\text { London, United Kingdom }\end{array}$ & $\begin{array}{l}\text { Acquisition of data and } \\
\text { critical review for } \\
\text { important intellectual } \\
\text { content }\end{array}$ \\
\hline $\begin{array}{l}\text { Simon } \\
\text { Rinaldi, MD }\end{array}$ & $\begin{array}{l}\text { University of Oxford and } \\
\text { Oxford University } \\
\text { Hospitals NHS Foundation } \\
\text { Trust }\end{array}$ & $\begin{array}{l}\text { Acquisition of data and } \\
\text { critical review for } \\
\text { important intellectual } \\
\text { content }\end{array}$ \\
\hline $\begin{array}{l}\text { Claudia } \\
\text { Steen, MD }\end{array}$ & $\begin{array}{l}\text { St Joseph Hospital, Berlin, } \\
\text { Germany }\end{array}$ & $\begin{array}{l}\text { Acquisition of data and } \\
\text { critical review for } \\
\text { important intellectual } \\
\text { content }\end{array}$ \\
\hline $\begin{array}{l}\text { Michael } \\
\text { Freilinger, } \\
\text { MD }\end{array}$ & $\begin{array}{l}\text { Medical University of } \\
\text { Vienna, Austria }\end{array}$ & $\begin{array}{l}\text { Acquisition of data and } \\
\text { critical review for } \\
\text { important intellectual } \\
\text { content }\end{array}$ \\
\hline $\begin{array}{l}\text { Markus } \\
\text { Breu, MD }\end{array}$ & $\begin{array}{l}\text { Medical University of } \\
\text { Vienna, Austria }\end{array}$ & $\begin{array}{l}\text { Acquisition of data and } \\
\text { critical review for } \\
\text { important intellectual } \\
\text { content }\end{array}$ \\
\hline $\begin{array}{l}\text { Rainer Seidl, } \\
\text { MD }\end{array}$ & $\begin{array}{l}\text { Medical University of } \\
\text { Vienna, Austria }\end{array}$ & $\begin{array}{l}\text { Acquisition of data and } \\
\text { critical review for } \\
\text { important intellectual } \\
\text { content }\end{array}$ \\
\hline $\begin{array}{l}\text { Markus } \\
\text { Reindl, PhD }\end{array}$ & $\begin{array}{l}\text { Medical University of } \\
\text { Innsbruck, Austria }\end{array}$ & $\begin{array}{l}\text { Acquisition of data, } \\
\text { interpretation of data, and } \\
\text { critical review for } \\
\text { important intellectual } \\
\text { content }\end{array}$ \\
\hline $\begin{array}{l}\text { Julia } \\
\text { Wanschitz, } \\
\text { MD }\end{array}$ & $\begin{array}{l}\text { Medical University of } \\
\text { Innsbruck, Austria }\end{array}$ & $\begin{array}{l}\text { Acquisition of data and } \\
\text { critical review for } \\
\text { important intellectual } \\
\text { content }\end{array}$ \\
\hline $\begin{array}{l}\text { Cinta Lleixà, } \\
\text { PhD }\end{array}$ & $\begin{array}{l}\text { Hospital de la Santa Creu i } \\
\text { Sant Pau, Universitat } \\
\text { Autónoma de Barcelona, } \\
\text { Barcelona, Spain }\end{array}$ & $\begin{array}{l}\text { Acquisition of data and } \\
\text { interpretation of data }\end{array}$ \\
\hline
\end{tabular}

Appendix (continued)

\begin{tabular}{|c|c|c|}
\hline Name & Location & Contribution \\
\hline $\begin{array}{l}\text { Günther } \\
\text { Bernert, MD }\end{array}$ & $\begin{array}{l}\text { Kaiser-Franz Josef Hospital } \\
\text { with Gottfried von Preyer } \\
\text { children Hospital, Vienna, } \\
\text { Austria }\end{array}$ & $\begin{array}{l}\text { Acquisition of data and } \\
\text { critical review for } \\
\text { important intellectual } \\
\text { content }\end{array}$ \\
\hline $\begin{array}{l}\text { Klaus-Peter } \\
\text { Wandinger, } \\
\text { MD, PhD }\end{array}$ & $\begin{array}{l}\text { University Hospital } \\
\text { Schleswig-Holstein, Kiel/ } \\
\text { Lübeck, Germany }\end{array}$ & $\begin{array}{l}\text { Acquisition of data and } \\
\text { critical review for } \\
\text { important intellectual } \\
\text { content }\end{array}$ \\
\hline $\begin{array}{l}\text { Ralf Junker, } \\
\text { MD }\end{array}$ & $\begin{array}{l}\text { University Hospital } \\
\text { Schleswig-Holstein, Kiel/ } \\
\text { Lübeck, Germany }\end{array}$ & $\begin{array}{l}\text { Acquisition of data and } \\
\text { critical review for } \\
\text { important intellectual } \\
\text { content }\end{array}$ \\
\hline $\begin{array}{l}\text { Luis Querol, } \\
\text { MD, PhD }\end{array}$ & $\begin{array}{l}\text { Hospital de la Santa Creu i } \\
\text { Sant Pau, Universitat } \\
\text { Autónoma de Barcelona, } \\
\text { Barcelona, Spain }\end{array}$ & $\begin{array}{l}\text { Acquisition of data, } \\
\text { execution, interpretation } \\
\text { of data, and critical review } \\
\text { for important intellectual } \\
\text { content }\end{array}$ \\
\hline $\begin{array}{l}\text { Frank } \\
\text { Leypoldt, } \\
\text { MD, PhD }\end{array}$ & $\begin{array}{l}\text { University Hospital } \\
\text { Schleswig-Holstein, Kiel/ } \\
\text { Lübeck, Germany }\end{array}$ & $\begin{array}{l}\text { Conception and design, } \\
\text { acquisition of data, } \\
\text { execution, interpretation } \\
\text { of data, and critical review } \\
\text { for important intellectual } \\
\text { content }\end{array}$ \\
\hline $\begin{array}{l}\text { Kevin } \\
\text { Rostásy, MD }\end{array}$ & $\begin{array}{l}\text { Witten/Herdecke } \\
\text { University, Children's } \\
\text { Hospital Datteln, Germany }\end{array}$ & $\begin{array}{l}\text { Conception and design, } \\
\text { acquisition of data, } \\
\text { statistical analysis, } \\
\text { execution, interpretation } \\
\text { of data, and critical review } \\
\text { for important intellectual } \\
\text { content }\end{array}$ \\
\hline $\begin{array}{l}\text { Romana } \\
\text { Höftberger, } \\
\text { MD }\end{array}$ & $\begin{array}{l}\text { Medical University of } \\
\text { Vienna, Austria }\end{array}$ & $\begin{array}{l}\text { Conception and design, } \\
\text { acquisition of data, } \\
\text { execution, interpretation } \\
\text { of data, and critical review } \\
\text { for important intellectual } \\
\text { content }\end{array}$ \\
\hline
\end{tabular}

\section{References}

1. Querol L, Devaux J, Rojas-Garcia R, Illa I. Autoantibodies in chronic inflammatory neuropathies: diagnostic and therapeutic implications. Nat Rev Neurol 2017;13: 533-547.

2. Martin-Aguilar L, Pascual-Goni E, Lleixa C, et al. Antibodies against nodo-paranodal proteins are not present in genetic neuropathies. Neurology Epub 2020 Feb 26.

3. Martinez-Hernandez E, Sepulveda M, Rostásy K, et al. Antibodies to aquaporin 4, myelin-oligodendrocyte glycoprotein, and the glycine receptor $\alpha 1$ subunit in patients with isolated optic neuritis. JAMA Neurol 2015;72:187.

4. Mathey EK, Garg N, Park SB, et al. Autoantibody responses to nodal and paranodal antigens in chronic inflammatory neuropathies. J Neuroimmunol 2017;309: 41-46.

5. Yuki N, Tagawa Y, Irie F, et al. Close association of Guillain-Barré syndrome with antibodies to minor monosialogangliosides GM1b and GM1 $\alpha$. J Neuroimmunol 1997;74:30-34.

6. Hadden R, Cornblath D, Hughes R, et al. Electrophysiological classification of Guillain-Barré syndrome: clinical associations and outcome. Ann Neurol 1998;44: $780-788$.

7. Ogata H, Yamasaki R, Hiwatashi A, et al. Characterization of IgG4 anti-neurofascin 155 antibody-positive polyneuropathy. Ann Clin Transl Neurol 2015;2:960-971. 


\section{Neurology $^{\odot}$ \\ Neuroimmunology \& Neuroinflammation}

\section{Antibodies to nodal/paranodal proteins in paediatric immune-mediated neuropathy Desiree De Simoni, Gerda Ricken, Michael Winklehner, et al. \\ Neurol Neuroimmunol Neuroinflamm 2020;7; DOI 10.1212/NXI.0000000000000763}

This information is current as of June 2, 2020

\section{Updated Information \& Services}

References

Citations

Subspecialty Collections

Permissions \& Licensing

Reprints including high resolution figures, can be found at: http://nn.neurology.org/content/7/4/e763.full.html

This article cites 6 articles, 0 of which you can access for free at: http://nn.neurology.org/content/7/4/e763.full.html\#\#ref-list-1

This article has been cited by 1 HighWire-hosted articles: http://nn.neurology.org/content/7/4/e763.full.html\#\#otherarticles

This article, along with others on similar topics, appears in the following collection(s):

Chronic inflammatory demyelinating polyneuropathy

http://nn.neurology.org//cgi/collection/chronic_inflammatory_demyeli nating_polyneuropathy

Guillain-Barre syndrome

http://nn.neurology.org//cgi/collection/guillainbarre_syndrome

Information about reproducing this article in parts (figures,tables) or in its entirety can be found online at:

http://nn.neurology.org/misc/about.xhtml\#permissions

Information about ordering reprints can be found online: http://nn.neurology.org/misc/addir.xhtml\#reprintsus

Neurol Neuroimmunol Neuroinflamm is an official journal of the American Academy of Neurology.

Published since April 2014, it is an open-access, online-only, continuous publication journal. Copyright Copyright $\odot 2020$ The Author(s). Published by Wolters Kluwer Health, Inc. on behalf of the American Academy of Neurology.. All rights reserved. Online ISSN: 2332-7812.

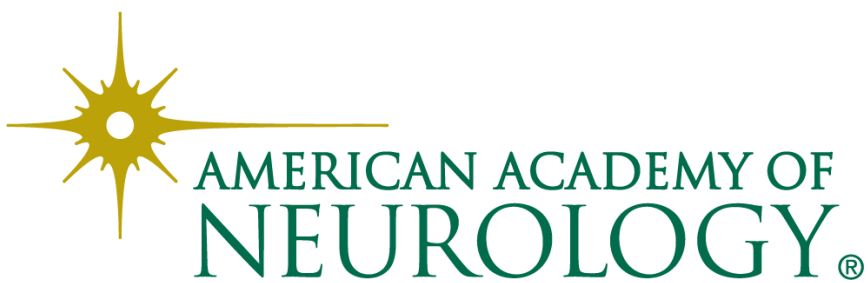

